\title{
DOES FEDERAL FINANCIAL AID AFFECT COLLEGE ENROLLMENT? EVIDENCE FROM DRUG OFFENDERS AND THE HIGHER EDUCATION ACT OF 1998
}

\author{
Michael F. Lovenheim \\ Emily G. Owens \\ Working Paper 18749 \\ http://www.nber.org/papers/w18749 \\ NATIONAL BUREAU OF ECONOMIC RESEARCH \\ 1050 Massachusetts Avenue \\ Cambridge, MA 02138 \\ February 2013
}

We would like to thank Sue Dynarski and Kirabo Jackson as well as seminar participants at Cornell University for helpful comments. We thank Blythe McCoy for excellent research assistance as well. No outside funding was received for this research, and the authors have no outside financial relationships to disclose that are relevant to this work. The views expressed herein are those of the authors and do not necessarily reflect the views of the National Bureau of Economic Research.

NBER working papers are circulated for discussion and comment purposes. They have not been peerreviewed or been subject to the review by the NBER Board of Directors that accompanies official NBER publications.

(C) 2013 by Michael F. Lovenheim and Emily G. Owens. All rights reserved. Short sections of text, not to exceed two paragraphs, may be quoted without explicit permission provided that full credit, including (๑) notice, is given to the source. 
Does Federal Financial Aid Affect College Enrollment? Evidence from Drug Offenders and the Higher Education Act of 1998

Michael F. Lovenheim and Emily G. Owens

NBER Working Paper No. 18749

February 2013

JEL No. H30,I28,K14

\begin{abstract}
In 2001, amendments to the Higher Education Act made people convicted of drug offenses ineligible for federal financial aid for up to two years after their conviction. Using rich data on educational outcomes and drug charges in the NLSY 1997, we show that this law change had a large negative impact on the college attendance of students with drug convictions. On average, the temporary ban on federal financial aid increased the amount of time between high school graduation and college enrollment by about two years, and we also present suggestive evidence that affected students were less likely to ever enroll in college. Students living in urban areas and those whose mothers did not attend college appear to be the most affected by these amendments. Importantly, we do not find that the law deterred young people from committing drug felonies nor did it substantively change the probability that high school students with drug convictions graduated from high school. We find no evidence of a change in college enrollment of students convicted of non-drug crimes, or of those charged by not convicted of drug offenses. In contrast to much of the existing research, we conclude that, for this high-risk group of students, eligibility for federal financial aid strongly impacts college investment decisions.
\end{abstract}

Michael F. Lovenheim

Department of Policy Analysis and Management

Cornell University

135 Martha Van Rensselaer Hall

Ithaca, NY 14853

and NBER

mfl55@cornell.edu

Emily G. Owens

Cornell University

Department of Policy Analysis and Management

137 MVR Hall

Ithaca, NY 14853

ego5@cornell.edu 


\section{Introduction}

Changes in the United States economy over the past several decades have led to historically high returns to obtaining a college degree (e.g., Autor et al. 2008). At the same time, because the cost of obtaining a college degree is also high, and growing, liquidity constrained students may under-invest in higher education. This concern is particularly salient for fragile populations, such as low-income families and students whose parents do not have a college education. In order to support lower-income students' ability to afford college, the Federal Government provides financial assistance to these students, typically in the form of Pell Grants and Stafford Loans. Federal aid is quite generous - in the 2009-2010 school year alone, the U.S. government gave out over $\$ 42$ billion in grant aid and over $\$ 100$ billion in loan aid to college students (College Board 2011). A question of central concern is how, or whether, this aid impacts the likelihood that high school graduates, in particular those from disadvantaged backgrounds, enroll in and graduate from college.

Despite the high policy importance of identifying how financial aid affects college investment decisions, research on federal aid is scant and is hampered by the fact that, by construction, cross-sectional variation in federal student aid is correlated with differences across students in family finances. The amount of aid available to any particular student is therefore almost certainly correlated with unobserved factors that also affect the likelihood of investing in college. A lack of exogenous variation across students in aid eligibility makes it difficult to credibly identify the effect of federal student aid for college on postsecondary investment using the current federal financial aid system.

Recent reviews of the financial aid literature (Deming and Dynarski 2009, Kane 2006) highlight the lack of consistent results. Early quasi-experimental research on the introduction of 
the Pell Grant system in the 1970s finds little effect of the program on college enrollment among recent high school graduates (Hansen 1983, Kane 1994, Kane 1995). ${ }^{1}$ However, changes in the higher education system in the US since that time make these results difficult to extrapolate to more recent cohorts of students.

Some more recent studies present some evidence that federal financial aid grants can increase college enrollment. For example, Dynarski (2003) examined the 1982 revocation of Supplemental Security Income (SSI) benefits for college-age children with deceased parents. Using a difference-in-difference methodology, she finds that each $\$ 1000$ in SSI aid increased college enrollment by 3.6 percentage points. This paper was distinguished from previous work on federal aid both in its use of plausibly exogenous aid eligibility as well as in the salience of the aid. Students eligible for SSI received the grant automatically if they enrolled in college. In contrast, students need to apply for other sources of federal aid by filling out the Free Application for Federal Student Aid (FAFSA), which is a long and cumbersome process that can deter many needy students from applying (Dynarski and Scott-Clayton, 2006). Indeed, Bettinger et al. (2012) highlight this point by conducting an experiment through H\&R Block in which they fill out FAFSA forms for a randomly selected group of low-income tax filers with college-age children. They find that filling out this form leads to large increases in college-going and collegiate attainment, suggesting both that receiving federal financial aid positively affects college investment decisions and that the current manner in which the federal aid system operates dissuades many low-income students from accessing aid. ${ }^{2}$

\footnotetext{
${ }^{1}$ Seftor and Turner (2002) demonstrate that enrollment among older, "non-traditional" students increased with the introduction of the Pell Grant. Furthermore, it is important to note that these results all assume that counterfactual enrollment trends were not declining.

${ }^{2}$ There also is a sizable related literature examining the effect of state merit aid on college enrollment and completion. Similar to the estimates from the federal aid literature, these studies tend to find mixed results (see
} 
This paper contributes to the financial aid literature by examining the effect of a unique, short-term shock to the availability of federal financial among an at-risk population: teens convicted of a drug offense. The 1998 amendments to the Higher Education Act (HEA98) specified that, beginning in 2001, any student convicted of a drug offense was ineligible for federal financial aid for one to two years post-conviction, depending on the student's criminal record. We use this rule change in a difference-in-difference framework, comparing college attendance among those with and without drug convictions in the years surrounding the law change, using the 1997 National Longitudinal Survey of Youth. While not without limitations, this data set allows us to observe detailed criminal history information as well as data on student characteristics, cognitive ability, and postsecondary investment.

Our analysis builds on previous work on federal aid by focusing on an important and understudied group of at-risk students, for whom the social returns to higher education and human capital investment may be particularly high (Lochner 2004). Furthermore, our empirical strategy exploits changes in eligibility for federal financial aid as it is currently experienced by students. This analysis is the first to estimate how students respond to exogenous federal aid eligibility changes that operate through the current FAFSA application process, rather than manipulation of the process itself, as in Bettinger et al. (2012).

In contrast to the early research on Pell grants, we find that HEA98 significantly and substantially reduced the probability that students with drug convictions attended college immediately after graduating from high school. Student responses are highly consistent with the structure of the law: we estimate that students with drug convictions took an average of 28 additional months to enroll in college post-HEA98, which is statistically indistinguishable from 
the specified two year ineligibility period.

Due to the relatively small number of treated students, the magnitude of our estimates is somewhat sensitive to the inclusion of student characteristics. However, when focusing on those who have the highest predicted likelihood of having a drug conviction, as well as on the most atrisk subsamples - those whose mothers did not attend college and students living in urban areas - our enrollment estimates remain large and are stable with respect to the inclusion of additional controls.

We also are able to rule out many other plausible alternate explanations for our results. The data indicate that students did not delay high school graduation in response to the eligibility change, and there is no evidence that the HEA98 deterred students from committing drug crimes. HEA98 appears to have had little impact on students with other types of criminal records as well; our results are inconsistent with changes in college enrollment among students convicted of nondrug crimes over this time period, and we do not observe any impact on students charged, but not convicted, of a drug offense. Finally, we conduct a series of permutation tests to verify that our estimated effects are not driven by outliers.

Our estimates are suggestive of a small effect of the eligibility change on the probability students with drug convictions ever attend college or obtain a bachelor's degree (BA). However, these estimates are imprecise due to the small number of individuals with drug convictions in our sample. Overall, the largest impact of the law is on delayed entry into college: HEA98 created an involuntary "double gap year" for the most at-risk students of an at-risk group. While most of these students eventually enroll, such delays reduce the returns to a college education, as the higher wages that accompany collegiate attainment are realized for two fewer years.

By necessity, we focus on a select sample of disadvantaged students with a recent drug 
conviction, since that is the group affected by HEA98. On the one hand, this presents a potential limitation in generalizing our results to a larger group of low-income and at-risk students, although the extent to which the response of students with drug convictions to financial aid would differ systematically from the response of disadvantaged students more generally is unclear. On the other hand, drug offenders are of particular policy interest. Since the law was passed, the fraction of adults with a criminal history has grown by over 20\% (Guerino et al. 2010). At the same time, federal and state policy has continued to evolve in a way that has deliberately excluded ex-felons from many sources of employment and social support, including federal contract work, federally funded housing assistance, TANF, and food stamps (GAO 2005). To the extent that these policies make it more difficult for those with criminal records to participate in the legitimate sector, they may increase the likelihood that these people return to illegal activity (Bushway and Sweeten 2007). The high social cost of crime makes any policy affecting outcomes for this high-risk group of individuals worth examining.

The paper proceeds as follows: in the next section, we provide additional background on the HEA98 as well as long run trends in drug convictions. We then describe our data and analytic approach in Section 3. Section 4 presents results, and we conclude with a discussion in Section 5.

\section{The Higher Education Act of 1998 and Juvenile Drug Convictions}

The main purpose of the HEA98 was to re-authorize the Higher Education Act of 1965, which was the original act that set up the current federal financial aid system. However, the HEA98 included a provision that restricts the federal financial aid eligibility of students who have been convicted of drug-related offenses. The amendment specifically stated that:

"A student who has been convicted of any offense under any Federal or State law involving the possession or sale of a controlled substance shall not be eligible to receive any grant, loan, or work assistance under this title during the period beginning on the date of such conviction..." 
The ineligibility period was one year for the first possession conviction, two years for the second, and an indefinite ban for a third offense. Students convicted of selling a controlled substance were ineligible for two years after a first offense and indefinitely for subsequent offenses. Under the law, students could regain eligibility earlier if they completed a drug rehabilitation program that included unannounced drug tests and was recognized by a federal or state licensed medical board. The temporary aid ban went into effect in 2001, and through 2007, the FAFSA asked students whether they have been convicted of possession or sale of illegal drugs in state or federal court. Students who failed to answer the drug conviction question were ineligible for financial aid (GAO 2005). ${ }^{3}$ The eligibility provision in the law does not distinguish between felony and misdemeanor convictions or state versus federal convictions and does not explicitly exclude convictions in juvenile court, which most states include as part of an offender's official criminal history until age twenty three (Owens 2009). ${ }^{4}$ Any drug offense made one ineligible for aid for at least one year. ${ }^{5}$

Using the 2003-2004 National Postsecondary Student Aid Survey (NPSAS), the GAO (2005)

\footnotetext{
${ }^{3}$ From 2007 onward, students were only asked about convictions that occurred while they were receiving federal financial aid, meaning that all first-time applicants were eligible on this margin. This is not relevant for our study, as our period of analysis extends through 2003.

${ }^{4}$ It is important to note that the federal government in general, and in particular the Department of Education, currently lacks the ability to validate one's response to this question with certainty. While it is illegal to lie on the FAFSA, some students may do so in order to obtain aid. Particularly for state-level drug convictions, it would be very difficult for the government to check whether each student does not have a drug conviction. Bushway et al. (2007) highlight the prevalence of both false negatives and false positives in most criminal background checks. If students systematically misrepresented their criminal history on the FAFSA after the HEA98 went into effect, then we would not expect the law change to reduce the college enrollment rate of drug offenders.

${ }^{5}$ The zero-tolerance approach of HEA98 was consistent with trends in federal drug policy at the time but was actually counter to state-level movements lowering the expected cost of drug use. In 2000, Nevada, Colorado, and Hawaii became the seventh, eighth, and ninth states to decriminalize the possession of small amounts of marijuana for personal medical use, which the U.S. Supreme Court ruled in 2001 was still an unlawful act (USA v. Oakland Cannabis Buyers' Cooperative (OCBC) and Jeffrey Jones). Neither the state laws nor the Supreme Court ruling had a clear impact on the likelihood that students with drug convictions attended college or delayed college enrollment. These states also represent a very small fraction of our sample, and we demonstrate below that the likelihood of a drug conviction does not shift in 2001, which suggests that these state changes are unlikely to produce a bias in our estimates.
} 
reported that about 41,000 students were denied aid due to a drug-related conviction, and this estimate excludes those who do not apply because of a previous drug conviction. While a small proportion of the population of college students, this provision impacts a non-trivial number of people, who are likely to be drawn disproportionately from lower socioeconomic backgrounds. Black males are overrepresented in the criminal justice system overall, and they are particularly overrepresented among drug offenders. Based on a sample of felony defendants convicted in state courts in 2000 , roughly $53 \%$ of drug offenders were black and $83 \%$ were male. For sake of comparison, $44 \%$ of violent offenders and $39 \%$ of property offenders in that year were black, and $91 \%$ and $75 \%$, respectively, were male. In other words, the black and male students who, based on the demographics of those involved in the criminal justice system, are the most likely to be affected by HEA98 are also the least likely to attend college, ceteris paribus. ${ }^{6}$

Ex Ante, the net social cost of HEA98 is unclear for a number of reasons. First, it is not obvious what effect, if any, this regulation has on college investment. While any increase in the cost of enrolling in college should reduce the probability that students go, existing research has not found consistent impacts of federal aid on college attendance, particularly in the absence of changing the FAFSA application process. Furthermore, even if the marginal impact of federal aid on attendance was non-zero, the average treatment effect of HEA1998 may be particularly small, as those with drug convictions may be unlikely to attend college regardless of financial aid eligibility. $^{7}$

Second, even if HEA98 did impact college enrollment, there are arguably both social costs

\footnotetext{
${ }^{6}$ See Kane (1994) for trends in black-white differences in college enrollment and Bound, Lovenheim and Turner (2010) and Goldin, Katz, and Kuziemko (2006) for trends in male-female college enrollment. These papers show that women are more likely to attend college than men and that African American students are less likely to attend than are white students.

${ }^{7}$ People convicted of drug felonies are generally less civically engaged for reasons besides the conviction (Sweeten et al. 2009, Hjalmarsson and Lopez 2010).
} 
and social benefits to this law. If HEA98 discouraged high-risk students from enrolling in college, any standard model of human capital formation and crime would predict that this would increase criminal behavior of affected students (Becker 1968, Lochner and Moretti 2004, Lochner 2004, Mocan et al. 2005). At the same time, to the extent that HEA98 increased the cost of engaging in drug related activity, forward looking students may have been deterred by this law, reducing their participation in illegal drug markets. The remainder of this paper examines empirically how HEA98 affected college investment and drug convictions in order to provide evidence on the empirical relevance of these costs and benefits of HEA98.

\section{Estimating the Impact of HEA98 on College Attendance}

\subsection{Data}

We estimate the impact of HEA98 on the college attendance of drug convicts using the NLSY97. This nationally representative sample of 12-18 year olds in 1997 contains self-reported data on educational attainment, interaction with the criminal justice system, and a rich set of demographic characteristics. As in all nationally representative surveys, roughly $1 \%$ of respondents report being convicted of a drug offense, ${ }^{8}$ but the fact that we observe both education and criminal justice outcomes makes it uniquely suited to evaluate the HEA98. Further, the fact that drug convictions are self-reported means that we are essentially observing the same type of criminal information the student is asked to self-report on the FAFSA, although the NLSY97 is arguable more likely to be accurate, as responses are anonymous. However, we do make some minor adjustments to the data set to address issues of plausible effect size and endogenous selection into the "treatment."

\footnotetext{
${ }^{8}$ For example, in the 2003 Monitoring the Future, roughly $8 \%$ of high school seniors reported ever being arrested for any reason (http://www.albany.edu/sourcebook/pdf/t343.pdf). According to the Uniform Crime Reports, overall drug offense arrest rates were about $0.4 \%$ in this time period (http://bjs.ojp.usdoj.gov/content/pub/pdf/aus8009.pdf).
} 
Any impact of HEA98 on college enrollment may be statistically muted by the inclusion of NLSY97 respondents who are not eligible to enroll in college. We therefore restrict our analysis to high school graduates only, because these are the students who are on the margin of college enrollment. While this restriction could bias our estimates if students with drug convictions are more or less likely to graduate from high school after HEA98, we show below that no such response is evident in the data.

Our identification strategy consists of comparing the change in college enrollment likelihoods of students who were convicted of drug offenses to those who were not before and after 2001. Determining treatment status thus is critical to accurately identifying any effects of this rule change on college attendance. Because of the three year delay in when HEA98 went into effect, students may have anticipated the 2001 change and altered their schooling investment decisions as a result. We therefore assign each student to a "synthetic cohort" based on the year and month of birth and then assign students to treatment status based on the year in which they turn 18. Students who turn 18 in the 2000-2001 school year or after are considered to be subject to the HEA98 provisions. $^{9}$

Using information on the type and dates of convictions, we identify whether or not each student was convicted of a drug offense in the two years prior to the date of expected graduation, which is based on his synthetic cohort. For example, if a student is in the synthetic cohort expected to graduate in spring 2002, he is "treated" if he was convicted of a drug offense in any time between 2000 and 2002. As discussed in Section 2, HEA98 prohibits drug offenders from obtaining financial aid for different time periods, depending on how many convictions they have

\footnotetext{
${ }^{9}$ We also have assigned treatment status based on the expected year of graduation using one's grade in 1997 , assuming each student does not skip or repeat a grade from the time of first observation. This method of assigning treatment status yields similar results, and these estimates are available upon request from the authors.
} 
and what type of drug offense they were convicted of. Given the small sample of students with drug convictions, we use the most expansive definition in order to maximize power. Our twoyear window, which corresponds to one's second possession offense and first sales offense, catches the most students who are potentially affected by the restriction. ${ }^{10}$ About $1.2 \%$ of the high school graduates in NLSY97 have a drug conviction within two years of their predicted graduation date. Overall, there are 41 high school graduates with a drug conviction pre-2001 and 46 in the post-2001 period. $^{11}$

The NLSY97 also contains a large amount of information about student academic and socioeconomic backgrounds that allows us to both test for and control for differential selection into drug convictions surrounding HEA98. In particular, all respondents are given the Armed Services Vocational Aptitude Battery (ASVAB), which is a cognitive skills test used by the military. It is widely used in empirical work to measure student cognitive ability (e.g., Belley and Lochner, 2007; Lovenheim and Reynolds, 2011, Lovenheim and Reynolds, 2013). We also construct measures of household composition in 1997 (single parent, two parents or other parental structure), the number of household members under 18 , mother's age at $1^{\text {st }}$ birth, mother's age at respondent's birth, Census region, urban status and household income in 1997. We control separately for mother's and father's educational attainment (less than high school, high school diploma, some college, college graduate) as well as for gender and race. Table 1 presents descriptive statistics for all controls used in the analysis, which we show separately by pre- and post-2001 as well as by drug conviction status.

\footnotetext{
${ }^{10}$ To the extent that we mis-classify some offenders with convictions more than a year prior to their FAFSA application, our estimates will be biased towards zero.

${ }^{11}$ While 46 treated observations is a small number, such small samples are not uncommon in this literature. For example, in the Dynarski (2003) difference-in-difference analysis examining the effects of the end of SSI payments for college on enrollment, she has 54 treated observations, which is only slightly larger than the number we have here.
} 


\subsection{Estimation Strategy}

The estimation strategy we employ is to compare the change in the likelihood of college enrollment between drug offenders and non-offenders when HEA98 goes into effect in 2001. The central difference-in-difference model we estimate is as follows:

$$
\begin{aligned}
P\left(\text { Attend }_{i t}=\alpha\right. & +\delta_{1} \text { Post }_{t}+\delta_{2} \text { Convict }_{i}+\beta\left(\text { Post }_{t} * \text { Convict }_{i}\right)+\vartheta X_{i t}+\lambda\left(\text { Post }_{t} * X_{i t}\right) \\
& +\gamma\left(\text { Convict }_{i} * X_{i t}\right)+\varepsilon_{i t},
\end{aligned}
$$

where Attend is an indicator equal to 1 if the student attends college within two years of high

school graduation. ${ }^{12}$ We examine enrollment within two years because of our use of a two-year window for convictions and in order to focus our analysis on "traditional" students who attend college directly after high school. The variable Post is an indicator for the 2001-2003 synthetic cohorts, Convict is an indicator for whether the student was convicted of a drug offense in the previous two years, and $X$ is a vector of observable characteristics that were described in Section 3.1.

Recent work by Bound, Lovenheim and Turner (2010) and Bailey and Dynarsky (2011) demonstrate a changing relationship between gender, race, family income and college attendance over time. It also is plausible that the impact of having a drug conviction varies by socioeconomic status; being convicted of a drug offense may matter less for high-performing students, or for those from high-income families. Furthermore, random variation in the composition of drug offenders due to the small number of such offenders in the data could bias our estimates. We therefore interact all of our control variables in $X_{i t}$ with Post $t_{t}$, and with Convict $t_{i}$, allowing for us to control more flexibly for any relationship between demographics and college attendance that may be correlated with treatment status. These interactions control for

\footnotetext{
profit.

${ }^{12}$ College enrollment includes any enrollment in a two- of four-year school, whether public, private or non-
} 
any secular shifts in the observable characteristics of student post-HEA98 and control for differences in the relationship between observable characteristics and college enrollment by drug conviction status.

The coefficient of interest in this model is $\beta$, which is the difference-in-difference estimate conditional on the observable characteristics as well as on those characteristics interacted with Post and Convict indicators. The central identifying assumption required to interpret $\beta$ as causal is that the only reason for a change in the relative enrollment rates between drug offenders and non-offenders post-2001 is the financial aid restrictions in HEA98. The major threat to identification comes from the fact that HEA98 did not go into effect for three years after its passage and only applied to people convicted of drug offenses after 1999 (who would be filling out the FAFSA in 2001). This lag between the enactment and implementation could cause a potentially endogenous reduction in the fraction of students committing drug crimes and/or a strategic manipulation of when someone with a drug arrest was convicted.

We address this selection problem in several different ways. First, any change in the types of students who are convicted of drug offenses when HEA98 goes into effect should become apparent in the extensive set of background characteristics that we observe. For example, if relatively higher-achieving students were less likely to have drug convictions post-2001, then we might estimate $\beta$ to be negative, but this positive effect could be due to the fact that convicts post-2001 were less qualified for college and would not be due to less access to financial aid.

Table 1 presents descriptive statistics of the students in our sample by predicted graduation date and offender status. The final column of the table provides difference-in-difference estimates that test whether observable differences between drug offenders and non-offenders shifted post-2001. First, note that relative to their peers, students with drug convictions are 
disadvantaged on almost all margins - their parents have less education, their family incomes are lower, they are more likely to live in single-parent households, and they are more likely to live in urban areas. Those convicted of drug offenses also are much more likely to be male. However, as the difference-in-difference estimates show, we cannot reject the null hypothesis that there was no change in these differences surrounding the implementation of HEA98 in 2001. The difference-in-difference estimates typically are small relative to the underlying means, and in only one case is the estimate statistically significantly different from zero at the $5 \%$ level. Furthermore, the point estimates suggest drug offenders are becoming more advantaged over time rather than less relative to their non-offender counterparts. Drug offenders also are slightly more likely to be white over time. Note that these differences will serve to bias our estimate of $\beta$ towards zero in models in which these observable characteristics are not controlled for. To the extent that there are unobserved changes in the likelihood of enrolling for college that are correlated with these small demographic differences, it suggests our difference-in-difference model may understate the importance of financial aid for college enrollment.

$<$ table 1 about here >

A common criticism of the NLSY97 is that item non-response for key demographic variables is prevalent. If the pattern of missing data is systematically related to our treatment variables, such non-response is particularly problematic. In Table 2, we present group-level means and difference-in-difference estimates of the probability that missing parental education, income, ASVAB score, and mother's fertility history are related to the effective date of HEA98. As in Table 1, we find no evidence of a differential change in the probability that drug offenders and non-offenders do not report this information, and the estimated magnitude of the differences are 
small relative to the group means. ${ }^{13}$

$<$ table 2 about here $>$

Another way to test for selection is to see whether there were differential pre-treatment trends in college enrollment between drug offenders and non-offenders. In particular, if college enrollment among drug offenders was declining over time, we could confound this secular decrease with the effect of the change in the financial aid rule. In Figure 1, we plot the fraction of people attending college within two years after they graduate from high school, again based on their predicted year of graduation. Students without drug convictions should not be affected by HEA98, and indeed there is no shift in college attendance among this group in 2001. Prior to 2001, there is a modest upward trend in the fraction of people with drug convictions that go to college. But after 2001, the first year that drug offenders were ineligible for federal aid, this trend reverses. Based on the graphical evidence, there is a roughly 12 percentage point (or 33\%) drop in college attendance, with no recovery by 2003. Furthermore, the same drop is not present for those only charged with a drug offense, as Figure 1 also demonstrates. In fact, college attendance rises slightly throughout our sample of people charged with drug offenses, while it declines precipitously among those convicted of drug crimes beginning in the 2001 cohort.

\section{<figure 1 about here>}

Together, Table 1 and Figure 1 show that any bias in our estimate of $\beta$ must be due to a shift in the underlying likelihood of attending college among those convicted of drug offenses in the 2001-2003 cohorts relative to the previous cohorts in a manner that is (1) unrelated to the

\footnotetext{
${ }^{13}$ Note that we include missing indicators in equation (1) interacted with conviction status and the Post dummy, which we prefer because AFQT and family income, in particular, explain a substantial fraction of the variation in college attendance. While it is potentially problematic to include missing data indicators, replicating our analysis with a more conservative set of control variables, excluding any variables with missing values, produces estimates that are substantively identical to the ones presented here. These results are available on request.
} 
extensive characteristics we observe and (2) not forecasted by pre-treatment trends. One possible shift could be an endogenous change in the likelihood of engaging in drug-related behaviors due to the law. Indeed, the main argument for the drug provisions in HEA98 was to deter teens from such activities; by raising the cost of conviction, HEA98 may have deterred some individuals from engaging in drug crimes.

The marginal drug offender deterred by the changes in federal law, including HEA98, would arguably be more likely to attend college than infra-marginal drug offenders, and therefore such a deterrent effect could lead to a spurious negative correlation between HEA98 and college attendance. The same would be true if police officers, prosecutors, or judges were less likely to convict marginal drug offenders if that conviction would impact their ability to receive federal financial aid.

We can explicitly test for such a deterrent effect by estimating a slight modification of equation (1), where we analyze whether or not the effective date of HEA98 changed the probability that a student has a drug conviction, was charged with a drug offense, or was convicted conditional on being charged. We limit this analysis to high school graduates, as these are the individuals included in our estimation of equation (1).

$<$ Table 3 about here $>$

The results from this analysis are presented in Table 3 . When we do not condition on observables, we actually find that high school graduates are just over $40 \%$ more likely to be convicted of a drug felony after HEA98 (column i), are 30\% more likely to be charged with a drug offense (column iii) and are $11 \%$ more likely to be convicted conditional on being charged. This is exactly the opposite effect we would expect in any standard model of deterrence or 
compensating behavior on the part of prosecutors. ${ }^{14}$ When we condition on demographic characteristics (columns ii, iv and vi), the direction of the selection effect reverses, but the magnitudes of the coefficients are small in absolute terms and relative to the sample mean and are not statistically different from zero at conventional levels. We therefore conclude that any contamination of our treatment effect due to endogenous compositional change is minimal at most. Table 3 also suggests that the law did not have the intended effect: drug crimes among prospective college students were not reduced.

Thus, there is little evidence of a demographic shift in any particular set of characteristics of drug offenders surrounding HEA98. Visually, there is a sharp dropoff in college attendance among offenders when the financial aid provisions of HEA98 come into effect that is not forecasted by pre-treatment trends. And, there is no evidence of an endogenous reduction in the likelihood of getting charged or convicted of a drug crime due to the law. These findings give us confidence that our estimate of $\beta$ is identifying the causal estimate of the financial aid restrictions embedded in HEA98.

\section{Results}

\subsection{Baseline Estimates}

Table 4 presents our central difference-in-difference estimates of the effect of HEA98 on college enrollment. In column (i), we do not condition our estimates on demographic changes, essentially replicating the estimate in the first row of Table 1 , and we find a statistically imprecise 12 percentage point reduction in the probability that drug offenders enrolled in college after 2001. While not precise, this is a large change relative to the pre-2001 attendance rate among drug offenders (36\%), and it also is large relative to the 27 percentage point difference in

\footnotetext{
${ }^{14}$ However, it is consistent with Pfaff (2011), who argues that a large fraction of the increased prison population is due to prosecutors filing more felony charges, conditional on arrest, over time.
} 
the college attendance rate across convicts and their peers (see Table 1). Though suggestive of a large impact of financial aid on two-year enrollment, the small number of convicts renders this estimate rather noisy.

We next add in controls for observable characteristics and their interactions with the treatment indicators sequentially. In column (ii), we include our basic controls for demographic characteristics. Variation in the composition of high school graduates explains much of the trend in attendance rates over time and slightly mitigates the differences in college attendance for offenders and non offenders. Conditional on demographics, we estimate that excluding drug offenders from aid eligibility reduces the probability they enrolled in college within two years of graduating high school by 16 percentage points, with a p-value of $11.5 \%$. While not statistically significant at conventional levels, this is a $44 \%$ decline relative to the baseline of $36 \%$.

\section{<Table 4 about here>}

Finally, in column (iii), we show our preferred specification, in which we relax our constraints on the relationship between individual characteristics and college enrollment over time and across groups. In contrast to the existing literature that finds negligible effects of FAFSA-based federal aid on college enrollment, we estimate that when drug convicts were excluded from federal aid, there was a 22 percentage point (or $61 \%$ ) reduction in the probability that they attended college immediately after high school. We can reject the null hypothesis that this effect is different from zero at the $5 \%$ level, but our small sample sizes lead to standard error bounds that encompass small and very large effects. Given the inconsistent findings in previous work about whether federal financial aid affects college-going (Kane 2006; Deming and Dynarski 2009), this estimate is notable and large. Denying drug offenders Pell grants and Stafford loans may have been functionally equivalent to preventing them from attending college 
for at least two years after graduating from high school.

A question raised by Table 4 is why the estimate becomes larger when we control for observable characteristics. If the larger point estimate is driven by shifts in the demographic makeup of convicts surrounding the 2001 law change, then it might point to changing selection of who is convicted of a drug offense post-2001. In Figure 2, we present trends in predicted college enrollment by cohort. We predict college enrollment in the pre-treatment sample using a logit model of the probability of enrolling in college two years after high school graduation as a function of all observables used in Table 4 except the Post and Convicted indicators. We then used the estimated coefficients from this model to predict enrollment for each respondent in our data.

Figure 2 shows that for the "not convicted" sample, there were no obvious changes in the demographic makeup of students that would predict a shift in college enrollment. There is a fair amount of year-to-year variability in the predicted college enrollment of the convicted sample. However, the trends in the figure do not point to a sharp break in observable characteristics of drug offenders in 2001, and instead suggest that our small sample size of offenders leads to idiosyncratic variation in their demographic makeup that happens to be correlated with the implementation of the financial aid rule in 2001. Our small treated sample makes our estimates more subject to bias from such variation, which highlights the need to control for a detailed set of demographics in our empirical specification.

Appendix Table A-1 shows some additional information on which observables are most correlated with the financial aid treatment and how the exclusion of each variable (or set of variables for categorical variables) affects our main estimates of the effect of financial aid on college enrollment. In the first column, we estimate equation (1) using the given variable as the 
dependent variable but controlling for all other observables as in column (iii) of Table 4 . In only one case do we see a statistically significant effect at even the $10 \%$ level. In the second column, we show estimates akin to column (iii) of Table 4, except we exclude the given variable or set of variables. These estimates show that our results are robust to excluding any variable from our model, which suggests our estimates are not being driven by changes in any single observable characteristic surrounding the policy change. Put differently, the year-to-year variation in the demographic makeup of drug offenders shown in Figure 2 is not due to any one variable, and the fact that our estimate grows when we control for observables is not due to our decision to include a specific observable in our model.

While the shifting demographic makeup of offenders combined with the small number of treated observations in the data render our estimates somewhat sensitive to the inclusion of demographic controls, our results may be more stable when examining specific subgroups that have a higher ex ante likelihood of conviction. This stability comes about because restricting to such sub-samples makes the treatment and control groups much more similar to each other, which would likely make their unobserved enrollment trends more similar to each other as well. In Table 5, we estimate equation (1) limited to three groups of students who might be more likely to be convicted of a drug crime: students whose mothers did not attend college, students living in urban places, and students whose observable characteristics make it more likely they will have a drug conviction. ${ }^{15}$ Furthermore, these groups represent more disadvantaged samples whose

\footnotetext{
${ }^{15}$ Arrest rates for drug offenses, like all crimes, are much higher in cities than in suburban or rural counties. For example, in 2002, there were roughly 589 drug arrests per 100,000 city residents, compared to 426 and 416 arrests per 100,000 residents in suburban and rural areas, respectively (Sourcebook of Criminal Justice Statistics Online, http://www.albany.edu/sourcebook/csv/t43.csv).
} 
college enrollment behavior also might be more sensitive to financial aid. ${ }^{16}$

$<$ Table 5 about here $>$

As shown in Panel A of Table 5, students whose mothers have no college education are between 26 and 38 percentage points less likely to attend college within two years when they are treated with the HEA98 aid restriction. All three estimates are significant at the $10 \%$ level or higher, and the estimates with all observables and with no observables are very similar to each other. Among those convicted of drug offenses prior to the enactment of HEA98, $43 \%$ of students whose mother did not attend college were enrolled within two years, so these effects are between 59 and 87 percent relative to baseline enrollment rates. Panel B, which shows results for urban students, presents similar findings. Here, the estimates vary little in terms of magnitude and statistical significance across columns as controls are added. Restricting aid eligibility for urban students with a drug conviction reduces their likelihood of enrollment by about 22 percentage points, which is about 59\% relative to the pre-treatment baseline enrollment rate.

In Panel $\mathrm{C}$, we restrict our estimation sample to those who have a higher predicted probability of having a drug conviction. We estimate this likelihood using a logit model of conviction as a function of observables in the pre-treatment period. We then predict the likelihood of conviction for all students, and the sample in Panel C consists of those who have above the median predicted likelihood of having a drug conviction. The estimates again are consistent across columns when controls are added and show that attendance drops by about 19 percentage points when drug convicts lose aid eligibility. This effect is about $59.5 \%$ relative to the baseline attendance rate and suggests that when one restricts the sample to those who are

\footnotetext{
${ }^{16}$ For example, Black et al. (2005) estimate that on average, each year of maternal education is associated with just over 2 more months of schooling for her children in an OLS framework, but IV results suggest that this may be due to other differences between mothers with high and low levels of education.
} 
more likely to have a drug conviction, the estimates are both similar to those in column (iii) of Table 4 and also are far more robust to the inclusion of demographic controls. Once we pare down the sample to those who are most likely to be treated as a function of exogenous background characteristics, there is large and statistically significant negative effect of aid ineligibility on college enrollment that is insensitive to the manner in which demographics are included in the model.

\subsection{Effects on Other Educational Outcomes}

Because our college attendance estimate examines two-year enrollment, it may confound the effects of HEA98 on delayed attendance and on ever attending college. In Table 6, we exploit the richness of the education data in the NLYS97 to better understand how HEA98 affected drug offenders. We include the full set of demographic controls and their interactions with Convicted $_{i}$ and Post $t_{t}$ in all reported specifications.

\section{$<$ Table 6 about here $>$}

In column (i), we show that, while HEA98 prevented drug offenders from attending college immediately after high school, there is weaker evidence that a temporary restriction on federal aid permanently reduced the chances that someone attended college. ${ }^{17}$ Drug offenders were 8 percentage points less likely to ever attend college after the law's enactment, but this point estimate is smaller than the standard error and about $1 / 5$ of the underlying mean likelihood of ever attending college. This estimate is suggestive of a long-run effect, but given the wide confidence interval it is not definitive. Consistent with a small long-run effect, we also find only suggestive evidence that HEA98 reduces the probability that high school students with drug

\footnotetext{
${ }^{17}$ The most recent year of NLSY97 data is 2009. So, by "ever attend college" we refer to the likelihood our respondents attend by 2009. In 2009, the youngest cohort is 25 , and while college attendance among older students is rising, the vast majority of college students first attend college by their early 20s (Fitzpatrick and Turner 2007).
} 
offenses graduate from a four- year college (column ii). While our estimate is large relative to the baseline graduation rate pre-2001 among drug offenders, the fact that very few students who have drug convictions obtain a BA regardless of financial aid eligibility implies that we have a limited ability to detect any effect on college completion given our small sample size of drug offenders.

The HEA98 stipulated that after one to two years most drug offenders would once again be eligible for federal aid, depending on the number of past offenses. The temporary nature of the ban makes time to enrollment a natural outcome of interest. In column (iii), we estimate that, on average, after 2001, drug offenders delayed college enrollment by 28 months $(\mathrm{se}=8.01) .{ }^{18}$ There is an $80 \%$ chance that drug offenders waited exactly 24 months, roughly the amount of time HEA98 required students arrested in their senior year of high school to wait before becoming eligible for aid, to enroll in college. Thus, it appears that the main effect of the law was to delay college entry, which creates potentially significant costs for students who have to wait several years longer to obtain the returns to a college education. ${ }^{19}$

Since the HEA98 waiting period began at date of conviction, drug offenders may have strategically manipulated when they graduated from high school in anticipation of being temporarily ineligible for federal aid. In column (iv) of Table 6, we estimate the amount of time it took each individual to complete high school. On average, students with drug offenses who are predicted to graduate after 2001 took almost 4 more months to complete high school. This effect is relatively small and is imprecisely estimated. At the same time, in column (v) we show that

\footnotetext{
${ }^{18}$ Note that time between high school and college enrollment is measured as of the actual month of high school graduation, not of the predicted month of graduation based on one's synthetic cohort.

${ }^{19}$ While most of these students will not obtain a BA, there is ample evidence in the literature of sizable returns to sub-baccalaureate training (e.g., Kane and Rouse 1995; Andrews, Li and Lovenheim 2012; Jepsen, Troske and Coomes 2011).
} 
HEA98 did not reduce the long-run likelihood of ever graduating from high school. This is an important result, as it suggests that our decision to condition on high school graduation should not introduce a bias into our estimates. Furthermore, these results imply that the vast majority of the increased delay in time to college enrollment among offenders in the 2001-2003 cohorts is due to waiting to enroll in college post-high school, rather than due to later high school graduation. ${ }^{20}$

< Figure 2 about here >

\subsection{Robustness Checks}

One potential limitation of our analysis is that, because of the small number of "treated" individuals, our estimates may be driven by a few outliers. In order to address this issue, we conducted a series of permutation tests. First, we re-estimated our preferred model, Table 4 column (iii), 46 times, excluding one treated individual each time. Panel A of Figure 3 presents all of estimated treatment effects from these regressions along with the bounds of the $95 \%$ confidence interval. All estimates are statistically different from zero at the $5 \%$ level and range from -0.24 to -0.18 . We then systematically eliminate each possible pair of treated individuals from our sample. These 1,036 different regressions, presented in Panel B of Figure 3, produce average treatment effects ranging from -0.27 to -0.15 , and $97.4 \%$ of them are statistically different from zero. Based on these tests, we conclude that, even with our limited sample, our results are unlikely to be statistical anomalies.

\section{$<$ Table 7 about here $>$}

Finally, in order to verify that we are picking up the impact of the HEA98 financial aid

\footnotetext{
${ }^{20}$ These alternate outcomes are replicated for our two subsamples in Appendix Table A-2. The results are qualitatively similar, with the exception of the delay and eventual college enrollment for graduates whose mother did not attend college. This group is less likely to "ever attend," and those who do attend delay attendance by only 3 months on average.
} 
restrictions rather than some unobserved shift in the composition of drug offenders or some contemporaneous unobserved shock, we conduct a series of falsification tests in which we vary our definition of "drug offenders." Again, the richness of the NLYS97 allows us to differentiate people who interacted with the criminal justice system but did not in the specific way that would make them ineligible for federal loans and grants.

First, in columns (i) and (ii) of Table 7, we replace Convicted $_{i}$ with Charged $_{i}$. Since our treated group now includes individuals who were only arrested and charged with drug crimes in addition to those who ended up being convicted, we expect that our treatment effect will be attenuated. Indeed, this is what we find. Columns (i) and (ii) of Table 7 show that the impact of delayed eligibility falls by $75 \%$ under this definition, and it no longer is statistically significant at even the $10 \%$ level. In columns (iii) and (iv), we verify that the difference between column (ii) of Table 6 and column (iii) of Table 4 is driven by these unaffected drug users by restricting our treated group to those who are charged, but not convicted, of drug offenses. We estimate the HEA98 caused an imprecise 6 percentage point increase in the probability that these students attended college two years after high school when we control for observables. Thus, the effects we estimate in our baseline models are not driven by differential impacts of general interaction with the criminal justice system post-HEA98 but are specifically driven by the differential impact of being convicted, which is consistent with the structure of HEA98.

In columns (v) and (vi) of Table 7, we focus on students who were convicted of drug offenses at least three years before they were predicted to graduate high school. Consistent with the language of HEA98, we find no evidence that these students were any less likely to enroll in college after high school. If anything, students with older drug convictions are more likely to attend college after 2001, but this estimate is very imprecisely estimated. Overall, Table 7 shows 
that the effects we estimate in Tables 4 and 6 are due to the differential effects of having a drug conviction within two years in the 2001-2003 cohorts, which gives us some confidence our estimates are identifying the causal impact of HEA98 on college enrollment behavior because this is the group one would expect to be affected given how the law is written.

In the last two columns, we perform a final falsification test exploring the impact of HEA98 on students convicted of non-drug offenses, such as violent crimes (e.g., assault or robbery), property offenses (e.g., burglary) and major driving offenses (e.g., drunk driving). While conviction for any of these offenses could result in incarceration, HEA98 did not affect the federal financial aid eligibility of these students. We estimate that, after the effective date of HEA98, high school seniors convicted of serious crimes are roughly 7 percentage points less likely to attend college within two years of graduating high school, which is $1 / 3$ of the change for drug offenders.

In a given year, roughly $44 \%$ of adults convicted of a drug offense have been convicted of some sort of felony in the past. ${ }^{21}$ Since criminals, especially juveniles, tend to commit multiple types of crimes (Blumstein et. al 1988), it is not surprising that about $20 \%$ of students in our sample with a drug conviction also have been convicted of another crime. In the final column of Table 7, we control for both the presence of a drug conviction and a non-drug conviction, allowing us to better address this confounding issue. These controls reduce the magnitude of the statistically imprecise impact of non-drug convictions by almost half, implying that the larger "treatment effect" estimated in column (vii) was due to non-drug offenders also having drug convictions. Column (viii) shows little evidence of a shift in the likelihood of a student with a non-drug offense attending college in 2001, while the estimate for drug offenders still is large

\footnotetext{
${ }^{21}$ See http://www.albany.edu/sourcebook/pdf/t553.pdf.
} 
and is statistically significant at the $10 \%$ level. Thus, consistent with the provisions in HEA98, only students with drug convictions reduced college enrollment in 2001, suggesting this reduction was a response to lack of access to federal financial aid rather than due to underlying trends in college participation among those with criminal convictions.

\section{Conclusion}

Due to the rising costs of college attendance and the growing importance of collegiate attainment for life outcomes, understanding how financial aid impacts postsecondary enrollment is of high importance. It is particularly important to identify the role of financial aid for underprivileged students, who attend college at much lower rates than their wealthier counterparts. Students who are convicted of felony drug charges are arguably among the most atrisk students in America. While their performance on achievement tests is comparable to their peers, these student come from poorer families with non-traditional parental arrangements, and their parents are less likely to have attended college. Furthermore, being convicted of any felony offense at a young age is a strong predictor of future violent criminal behavior (Blumstein and Cohen 1987). The opportunity cost of allowing these young people to continue to fail, while difficult to quantify precisely, is inarguably large.

Despite the importance of identifying the effect of financial aid in general and federal financial aid in particular on college enrollment, the previous literature has not reached a consensus, due predominantly to the difficulty in generating exogenous variation in aid access. This paper exploits a rule change from the Higher Education Act of 1998 that temporarily eliminated federal financial aid eligibility for students convicted of a drug offense in the previous two years. We show extensive evidence that this rule change created an exogenous decrease in financial aid eligibility for students with a drug conviction. 
Using NLSY97 data on college enrollment, student socioeconomic and cognitive backgrounds and criminal histories, we employ a difference-in-difference methodology that examines how college enrollment among drug offenders relative to non-offenders changed surrounding the implementation of HEA98 in 2001, the first year this rule went into effect. We find evidence that the temporary prohibition on federal aid caused a large decline in the fraction of drug offenders who enrolled in college within two years of graduating from high school, particularly for students living in urban areas and those whose mothers never enrolled in college. This decline was driven predominantly by elongating the time between high school and college; drug offenders on the margin of college enrollment simply waited to enroll until they were eligible again for aid. The effects on ever attending college (by 2009) and on BA completion are more modest. This elongation has costs, however, in the form of delaying the returns to collegiate attainment. In addition, we find no evidence that the law had a deterrent effect on drug offenses. Thus, by forcing drug offenders to wait two years before enrolling in college, HEA1998 lowered the lifetime earnings of these at-risk students without generating benefits to society through reduced crime.

While this paper identifies the effect of federal financial aid on college enrollment among a distinct set of students - drug offenders - they are of high interest because they are from low socioeconomic backgrounds and because they are at risk of committing more crime in the future. Attending college may be an important "turning point" in the lives of delinquent youths, on par with marriage or employment (Sampson and Laub 1990, Uggen 2000), and education, in particular post-secondary education, is strongly correlated with desistance from crime (Nuttall et al. 2003, Johnson 2001, Clark 2001). By restricting access to financial aid, HEA98 may have inadvertently harmed the long-run life outcomes of these at-risk students. Indeed, in our sample 
students with drug convictions are 0.8 of a percentage point $(\mathrm{se}=0.5)$, or $60 \%$, more likely to be convicted of another drug crime in the three years after high school graduation if they are subject to the HEA98 financial aid restrictions.

Despite the selected sample, this paper is the first in the literature to show evidence that modern federal financial aid eligibility impacts college decisions, and there is little reason to believe low-income students more generally respond in a fundamentally different way to the availability of this aid. Given the importance of understanding how federal financial aid impacts college-going decisions, more research on the impact of this aid on a more general group of students is needed. 


\section{REFERENCES}

Autor, David H., Lawrence F. Katz and Melissa S. Kearney. 2008. " Trends in U.S. Wage Inequality: Revising the Revisionists." Review of Economics and Statistics 90(2): 300-323.

Andrews, Rodney, Jing Li and Michael Lovenheim. 2012. "Quantile Treatment Effects of College Quality on Earnings: Evidence from Administrative Data in Texas." NBER Working Paper No. 18068.

Bailey, Martha, and Susan Dynarski. 2011. "Gains and Gaps: Changing Inequality in US College Entry and Completion” NBER Working Paper No. 17633.

Becker, Gary. 1968. "Crime and Punishment: An Economic Approach.” Journal of Political Economy 76(2): 169-217.

Bettinger, Eric, Bridget Terry Long, Philip Oreopoulos, and Lisa Sanbonmatsu. 2012. "The Role of Application Assistance and Information in College Decisions: Results from the H\&R Block FAFSA Experiment." Quarterly Journal of Economics 127(3): 1205-1242.

Blumstein, Alfred and Jacqueline Cohen. 1987. "Characterizing Criminal Careers" Science 28(237): 985-991.

Bound, John, Michael F. Lovenheim, and Sarah Turner. 2010. "Why Have College Completion Rates Declined? An Analysis of Changing Student Preparation and Collegiate Resources." American Economic Journal: Applied Economics 2(3): 129-157.

Bushway, Shawn; Shauna Briggs, Faye Taxman, Meridith Thanner, and Mischelle Van Brakle. 2007. "Private Providers of Criminal History Records: Do You Get What You Pay For?" in Bushway, Shawn D., Michael Stoll, and David Weiman (eds.) The Impact of Incarceration on Labor Market Outcomes. New York: Russell Sage Foundation Press. P. 174-200.

Bushway, Shawn and Gary Sweeten. 2007. "Abolish Lifetime Bans for Ex-Felons." Criminology and Public Policy 6:4:697-706.

Clark, D. 2001. "Analysis of Return Rates of the Inmate College Program Participants." State of New York Department of Correctional Services, Division of Program Planning, Research, and Evaluation Report.

College Board. 2011. "Trends in Student Aid 2011." Trends in Higher Education Series. College Board Advocacy and Policy Center: http://trends.collegeboard.org/downloads/Student_Aid_2011.pdf.

Cornwell, Christopher, David B. Mustard and Deepa Sridhar. 2006. "The Enrollment Effects of Merit-Based Financial Aid: Evidence from Georgia's HOPE Program." Journal of Labor Economics 24(4): 761-786. 
Cornwell, Christopher, Kyung Hee Lee, and David B. Mustard. 2005. "Student Responses to Merit Scholarship Retention Rules.” Journal of Human Resources 40(4): 895-917.

Deming, David and Susan Dynarski. 2009. "Into College, Out of Poverty? Policies to Increase the Postsecondary Attainment of the Poor.” NBER Working Paper No. 15387.

Dynarski, Susan. 2000. "Hope for Whom? Financial Aid for the Middle Class and Its Impact on College Attendance." National Tax Journal 53(3): 629-661.

Dynarski, Susan. 2003. "Does Aid Matter? Measuring the Effect of Student Aid on College Attendance and Completion." American Economic Review 93(1): 278-288.

Dynarski, Susan. 2008. "Building the Stock of College-Educated Labor." Journal of Human Resources 43(3): 576-610.

Dynarski, Susan, and Judith Scott-Clayton. 2006. "The Cost of Complexity in Federal Student Aid: Lessons from Optimal Tax Theory and Behavioral Economics." National Tax Journal 59(2): 319-356.

Fitzpatrick, Maria D. and Damon Jones. 2012. "Higher Education, Merit-Based Scholarships and Post-Baccalaureate Migration." Mimeo.

Fitzpatrick, Maria D. and Sarah E. Turner. 2007. "Blurring the Boundary: Changes in Collegiate Participation and the Transition to Adulthood." In S. Danziger and C.E. Rouse (ed.) The Price of Independence. New York: Russell Sage

Goldin, Claudia, Lawrence F. Katz, and Ilyana Kuziemko. 2006. "The Homecoming of American College Women: The Reversal of the College Gender Gap." Journal of Economic Perspectives 20(4): 133-156.

Goodman, Joshua. 2008. "Who Merits Financial Aid? Massachusetts' Adams Scholarship." Journal of Public Economics 92(10-11): 2121-2131.

Government Accountability Office (GAO). 2005. "Drug Offenders: Various Factors May Limit the Impacts of Federal Laws That Provide for Denial of Selected Benefits." United States Government Accountability Office Report to Congressional Requesters GAO-05-238, September.

Guerino, P.M., P.M. Harrison, and W. Sabol. 2010. Prisoners in 2010. NCJ 236096. Washington, D.C.: U.S. Department of Justice, Bureau of Justice Statistics. http://www.bjs.gov/content/pub/pdf/p10.pdf.

Hansen, W. Lee. 1983. "Impact of Student Financial Aid on Access." In Joseph Froomkin (ed.) The Crisis in Higher Education. New York: Academy of Political Science. 
Hjalmarsson, Randi and Mark Lopez. 2010. "The Voting Behavior of Disenfranchised Criminals: Would They Vote if They Could?" American Law and Economics Review 12(2): $265-$ 279.

Jepsen, Christopher, Kenneth Troske and Paul Coomes. 2009. "The Labor-Market Returns for Community College Degrees, Diplomas, and Certificates." University of Kentucky Center for Poverty Research Discussion Paper Series, DP2009-08.

Kane, Thomas J. 1994. "College Entry by Blacks since 1970: The Role of College Costs, Family Background, and the Returns to Education." Journal of Political Economy 102(5): 878911.

Kane, Thomas J. 1995. "Rising Public College Tuition and College Entry: How Well do Public Subsidies Promote Access to College?” NBER Working Paper No. 5164.

Kane, Thomas J. 2006. "Public Intervention in Post-Secondary Education," in Erik Hanushek and Finis Welch (eds.) Handbook of the Economics of Education, Vol. 2, Ch. 23, Amsterdam: Elsevier Science.

Kane, Thomas J. and Cecilia Elena Rouse. 1995. "Labor Market Returns to Two- and FourYear Colleges.” American Economic Review 85(3): 600-614.

Lochner, Lance and Enrico Moretti. 2004. "The Effect of Education on Crime: Evidence from Prison Inmates, Arrests, and Self-Reports." American Economic Review 94(1): 155-189.

Lochner, Lance. 2004. "Education, Work, and Crime: A Human Capital Approach.” International Economic Review 45(3): 811-843.

Lovenheim, Michael and C. Lockwood Reynolds. 2011. "Changes in Postsecondary Choices by Ability and Income: Evidence from the National Longitudinal Surveys of Youth." Journal of Human Capital 5(1): 70-109.

Lovenheim, Michael and C. Lockwood Reynolds. 2013. "The Effect of Housing Wealth on College Choice: Evidence from the Housing Boom." Journal of Human Resources.

Mocan, H. Naci, Stephen C. Billups and Jody Overland. 2005. "A Dynamic Model of Differential Human Capital and Criminal Activity.” Economica 72(288): 655-681.

Nuttall, J., Hollmen, L. and Staley, E. M. 2003. "The Effect of Earning a GED on Recidivism Rates." Journal of Correctional Education 54(3): 90-94.

Owens, Emily G. 2009. "More Time, Less Crime? Estimating the Incapacitative Effect of Sentence Enhancements" Journal of Law and Economics 52(3): 551-579. 
Pfaff, John. 2011. "The Causes of Growth in Prison Admissions and Populations" SSRN working paper 1884674.

Sampson, Robert. and John Laub. 1990. "Crime and Deviance over the Life Course: The Salience of Adult Social Bonds." American Sociological Review 55(5):609-27.

Scott-Clayton, Judith. 2011. "On Money and Motivation: A Quasi-Experimental Analysis of Financial Incentives for College Achievement.” Journal of Human Resources 46(3): 614-646.

Seftor, Neil and Sarah Turner. 2002. "Back to School: Federal Student Aid Policy and Adult College Enrollment.” Journal of Human Resources 5(2): 230-6.

Sjoquist, David L. and John V. Winters. 2012. Building the Stock of College-Educated Labor Revisited." Journal of Human Resources 47(1): 270-285.

Sweeten, Gary, Shawn Bushway, and Ray Paternoster. 2009. "Does Dropping Out of School Mean Dropping Into Delinquency?" Criminology 47(1):47-91. 
Table 1: Means and Standard Deviations of Analysis Variables

\begin{tabular}{|c|c|c|c|c|c|}
\hline \multirow[b]{2}{*}{ Variable } & \multicolumn{2}{|c|}{ Pre-Change } & \multicolumn{2}{|c|}{ Post-Change } & \multirow[b]{2}{*}{ D-D } \\
\hline & No Conviction & Conviction & No Conviction & Conviction & \\
\hline \multirow{2}{*}{ Attend College } & 0.623 & 0.358 & 0.651 & 0.269 & -0.117 \\
\hline & $(0.485)$ & $(0.485)$ & $(0.477)$ & $(0.448)$ & $(0.104)$ \\
\hline \multirow{2}{*}{ ASVAB (10,000 units) } & 5.390 & 5.027 & 5.435 & 5.753 & 0.681 \\
\hline & $(2.798)$ & $(2.543)$ & $(2.773)$ & $(2.475)$ & $(0.710)$ \\
\hline \multirow{2}{*}{ Household Income $(\$ 10,000)$} & 5.647 & 4.419 & 5.500 & 4.137 & -0.134 \\
\hline & $(4.599)$ & $(2.635)$ & $(4.558)$ & $(2.707)$ & $(1.167)$ \\
\hline \multirow{2}{*}{ Single Parent } & 0.262 & 0.397 & 0.241 & 0.367 & -0.009 \\
\hline & $(0.440)$ & $(0.495)$ & $(0.428)$ & $(0.487)$ & $(0.094)$ \\
\hline \multirow{2}{*}{ Two Parents } & 0.687 & 0.462 & 0.719 & 0.605 & 0.111 \\
\hline & $(0.464)$ & $(0.505)$ & $(0.450)$ & $(0.494)$ & $(0.099)$ \\
\hline \multirow{2}{*}{ Other Parental Structure } & 0.051 & 0.141 & 0.040 & 0.028 & $-0.110^{* *}$ \\
\hline & $(0.220)$ & $(0.352)$ & $(0.196)$ & $(0.168)$ & $(0.045)$ \\
\hline \multirow{2}{*}{ \# HH Members < 18} & 2.219 & 2.207 & 2.424 & 2.360 & -0.052 \\
\hline & $(1.178)$ & $(1.154)$ & $(1.145)$ & $(0.974)$ & $(0.250)$ \\
\hline \multirow{2}{*}{ Urban } & 0.686 & 0.884 & 0.690 & 0.813 & -0.074 \\
\hline & $(0.464)$ & $(0.325)$ & $(0.463)$ & $(0.394)$ & $(0.100)$ \\
\hline \multirow{2}{*}{ Mom Age at $1^{\text {st }}$ Birth } & 23.35 & 23.86 & 23.76 & 24.17 & -0.10 \\
\hline & $(4.62)$ & $(4.98)$ & $(4.78)$ & $(4.94)$ & $(1.06)$ \\
\hline \multirow{2}{*}{ Mom Age at Respondent Birth } & 25.72 & 25.68 & 26.40 & 27.09 & 0.73 \\
\hline & $(5.38)$ & $(4.83)$ & $(5.30)$ & $(5.36)$ & $(1.21)$ \\
\hline \multirow{2}{*}{ Northeast } & 0.188 & 0.301 & 0.183 & 0.231 & -0.066 \\
\hline & $(0.391)$ & $(0.464)$ & $(0.387)$ & $(0.426)$ & $(0.084)$ \\
\hline \multirow{2}{*}{ North Central } & 0.274 & 0.170 & 0.267 & 0.229 & 0.066 \\
\hline & $(0.446)$ & $(0.380)$ & $(0.443)$ & $(0.425)$ & $(0.096)$ \\
\hline \multirow{2}{*}{ South } & 0.332 & 0.330 & 0.333 & 0.428 & 0.098 \\
\hline & $(0.471)$ & $(0.476)$ & $(0.450)$ & $(0.500)$ & $(0.101)$ \\
\hline \multirow{2}{*}{ West } & 0.205 & 0.199 & 0.217 & 0.112 & -0.098 \\
\hline & $(0.404)$ & $(0.404)$ & $(0.412)$ & $(0.319)$ & $(0.088)$ \\
\hline \multirow{2}{*}{ Mother < High School } & 0.148 & 0.094 & 0.145 & 0.174 & 0.084 \\
\hline & $(0.356)$ & $(0.295)$ & $(0.392)$ & $(0.384)$ & $(0.080)$ \\
\hline \multirow{2}{*}{ Mother High School Diploma } & 0.381 & 0.426 & 0.350 & 0.256 & -0.139 \\
\hline & $(0.486)$ & $(0.502)$ & $(0.477)$ & $(0.442)$ & $(0.109)$ \\
\hline Mother Some College & 0.253 & 0.291 & 0.268 & 0.209 & -0.097 \\
\hline & $(0.435)$ & $(0.460)$ & $(0.443)$ & $(0.412)$ & $(0.099)$ \\
\hline Mother BA+ & 0.218 & 0.190 & 0.237 & 0.361 & 0.153 \\
\hline 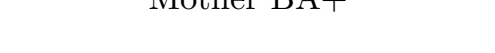 & $(0.413)$ & $(0.398)$ & $(0.425)$ & $(0.486)$ & $(0.095)$ \\
\hline Father $<$ High School & 0.161 & 0.228 & 0.152 & 0.166 & -0.053 \\
\hline Fatner < nign schoor & $(0.368)$ & $(0.427)$ & $(0.359)$ & $(0.378)$ & $(0.093)$ \\
\hline Father Hioh School Diploma & 0.367 & 0.521 & 0.385 & 0.499 & -0.041 \\
\hline Fatner mgn scnoor Diploma & $(0.482)$ & $(0.509)$ & $(0.487)$ & $(0.508)$ & $(0.124)$ \\
\hline Father Some Colleoe & 0.202 & 0.170 & 0.201 & 0.197 & 0.027 \\
\hline Fatner some Conege & $(0.401)$ & $(0.383)$ & $(0.401)$ & $(0.404)$ & $(0.103)$ \\
\hline & 0.271 & 0.080 & 0.261 & 0.138 & 0.067 \\
\hline Father BA+ & $(0.444)$ & $(0.277)$ & $(0.439)$ & $(0.350)$ & $(0.113)$ \\
\hline Black & 0.144 & 0.193 & 0.144 & 0.130 & -0.064 \\
\hline Black & $(0.351)$ & $(0.400)$ & $(0.351)$ & $(0.340)$ & $(0.076)$ \\
\hline Hisnani & 0.121 & 0.156 & 0.117 & 0.072 & -0.080 \\
\hline Hispanic & $(0.326)$ & $(0.368)$ & $(0.321)$ & $(0.262)$ & $(0.070)$ \\
\hline & 0.503 & 0.811 & 0.498 & 0.819 & 0.013 \\
\hline Male & $(0.500)$ & $(0.396)$ & $(0.500)$ & $(0.390)$ & $(0.107)$ \\
\hline Observations & 3,958 & 41 & 3,356 & 46 & 7,401 \\
\hline
\end{tabular}

All tabulations include only high school graduates. Standard deviations are in parentheses in the first four columns and Heteroskedasticity-robust standard errors are in parentheses in the D-D column: ** indicates statistical significance at the $5 \%$ level and * indicates statistical significance at the $10 \%$ level. 
Table 2: Means and Standard Deviations of Missing Indicator Variables

\begin{tabular}{cccccc}
\hline \hline \multirow{2}{*}{ Variable } & \multicolumn{2}{c}{ Pre-Change } & \multicolumn{2}{c}{ Post-Change } & \\
& No Conviction & Conviction & No Conviction & Conviction & D-D \\
\hline Mother's Education Missing & 0.066 & 0.100 & 0.058 & 0.073 & -0.018 \\
& $(0.249)$ & $(0.303)$ & $(0.233)$ & $(0.263)$ & $(0.052)$ \\
Father's Education Missing & 0.156 & 0.283 & 0.142 & 0.245 & -0.025 \\
& $(0.363)$ & $(0.456)$ & $(0.349)$ & $(0.435)$ & $(0.077)$ \\
Family Income Missing & 0.260 & 0.250 & 0.222 & 0.306 & 0.094 \\
& $(0.438)$ & $(0.438)$ & $(0.416)$ & $(0.466)$ & $(0.092)$ \\
ASVAB Missing & 0.172 & 0.293 & 0.163 & 0.252 & -0.032 \\
& $(0.378)$ & $(0.461)$ & $(0.369)$ & $(0.439)$ & $(0.081)$ \\
Mom Age at 1 ${ }^{\text {st }}$ Birth Missing & 0.068 & 0.099 & 0.067 & 0.069 & -0.030 \\
& $(0.252)$ & $(0.303)$ & $(0.251)$ & $(0.256)$ & $(0.054)$ \\
Mom Age at Respondent Birth Missing & 0.058 & 0.099 & 0.054 & 0.069 & -0.027 \\
& $(0.233)$ & $(0.303)$ & $(0.227)$ & $(0.256)$ & $(0.050)$ \\
\hline \hline
\end{tabular}

All tabulations include only high school graduates. Standard deviations are in parentheses in the first four columns and Heteroskedasticity-robust standard errors are in parentheses in the D-D column: ** indicates statistical significance at the $5 \%$ level and ${ }^{*}$ indicates statistical significance at the $10 \%$ level.

Table 3: Effect of The Financial Aid Policy Change on Drug Charges and Convictions

\begin{tabular}{|c|c|c|c|c|c|c|}
\hline \multirow[b]{2}{*}{ Independent Variable } & \multicolumn{2}{|c|}{ "I(Convicted) } & \multicolumn{2}{|c|}{ I(Charged) } & \multicolumn{2}{|c|}{ I(Convict|Charge) } \\
\hline & (i) & (ii) & (iii) & (iv) & (v) & (vi) \\
\hline Post-Change & $\begin{array}{r}0.005^{*} \\
(0.003)\end{array}$ & $\begin{array}{l}-0.001 \\
(0.007)\end{array}$ & $\begin{array}{c}0.007^{*} \\
(0.004)\end{array}$ & $\begin{array}{l}-0.001 \\
(0.010)\end{array}$ & $\begin{array}{c}0.056 \\
(0.083)\end{array}$ & $\begin{array}{l}-0.025 \\
(0.181)\end{array}$ \\
\hline Observables & No & Yes & No & Yes & No & Yes \\
\hline Dep. Var. Mean & \multicolumn{2}{|c|}{0.012} & \multicolumn{2}{|c|}{0.023} & \multicolumn{2}{|c|}{0.510} \\
\hline
\end{tabular}

All estimates include only high school graduates. Heteroskedasticity-robust standard errors are in parentheses: ** indicates significance at the $5 \%$ level and * indicates significance at the $10 \%$ level. 


\section{Table 4: Effect of Conviction on College Enrollment Surrounding Eligibil- ity Policy Change}

\begin{tabular}{clll}
\hline \hline Independent Variable & \multicolumn{1}{c}{ (i) } & \multicolumn{1}{c}{ (ii) } & (iii) \\
\hline Post*Convicted & -0.117 & -0.160 & $-0.220^{* *}$ \\
& $(0.108)$ & $(0.101)$ & $(0.091)$ \\
Convicted & $-0.266^{* *}$ & $-0.180^{* *}$ & $0.812^{* *}$ \\
& $(0.083)$ & $(0.079)$ & $(0.452)$ \\
Post-Change & $0.028^{* *}$ & 0.005 & -0.046 \\
& $(0.012)$ & $(0.023)$ & $(0.086)$ \\
$\mathrm{R}^{2}$ & & & \\
& 0.006 & 0.235 & 0.242 \\
Observables & No & Yes & Yes \\
Observables*Post & No & No & Yes \\
Observables*Convicted & No & No & Yes \\
\hline \hline
\end{tabular}

All estimates include only high school graduates. Heteroskedasticity-robust standard errors are in parentheses: ${ }^{* *}$ indicates significance at the $5 \%$ level and * indicates significance at the $10 \%$ level. 
Table 5: Effect of Conviction on College Enrollment Surrounding Eligibility Policy Change for Sub-Samples

\begin{tabular}{|c|c|c|c|}
\hline Panel A: Mother & $\operatorname{Sid} \operatorname{Not} A$ & tend Coll & \\
\hline Independent Variable & (i) & (ii) & (iii) \\
\hline Dost*Comiatol & $-0.313^{* *}$ & $-0.255^{*}$ & $-0.381^{* *}$ \\
\hline POSt Convicted & $(0.151)$ & $(0.143)$ & $(0.075)$ \\
\hline Convicted & -0.065 & -0.088 & $2.406^{* *}$ \\
\hline & $(0.124)$ & $(0.119)$ & $(0.441)$ \\
\hline Post-Change & $0.031^{*}$ & 0.049 & 0.040 \\
\hline & $(0.018)$ & $(0.036)$ & $(0.123)$ \\
\hline Total Obs/Treated Obs & & $3865 / 19$ & \\
\hline Panel B & Urban Sa & ple & \\
\hline Independent Variable & (i) & (ii) & (iii) \\
\hline Post*Convicted & $-0.220^{* *}$ & $-0.240^{* *}$ & $-0.218^{* *}$ \\
\hline & $(0.110)$ & $(0.106)$ & $(0.094)$ \\
\hline Convicted & $-0.278^{* *}$ & $-0.222^{* *}$ & 0.093 \\
\hline & $(0.089)$ & $(0.088)$ & $(0.441)$ \\
\hline Post-Change & $0.028^{* *}$ & 0.022 & 0.033 \\
\hline & $(0.014)$ & $(0.027)$ & $(0.103)$ \\
\hline Total Obs/Treated Obs & & $5379 / 38$ & \\
\hline $\begin{array}{l}\text { Panel C: Abo } \\
\text { Likeliho }\end{array}$ & $\begin{array}{l}\text { e Median } \\
\text { of Conv }\end{array}$ & $\begin{array}{l}\text { redicted } \\
\text { tion }\end{array}$ & \\
\hline Independent Variable & (i) & (ii) & (iii) \\
\hline Post*Convicted & $-0.185^{*}$ & $-0.188^{*}$ & $-0.192^{* *}$ \\
\hline & $(0.114)$ & $(0.110)$ & $(0.099)$ \\
\hline Convicted & $-0.249^{* *}$ & $-0.263^{* *}$ & 0.730 \\
\hline & $(0.093)$ & $(0.091)$ & $(0.496)$ \\
\hline Post-Change & $0.041^{* *}$ & 0.033 & $\begin{array}{l}-0.003 \\
(0.129)\end{array}$ \\
\hline Total Obs/Treated Obs & & $4066 / 38$ & \\
\hline Observables & No & Yes & Yes \\
\hline Observables*Post & No & No & Yes \\
\hline Observables*Convicted & No & No & Yes \\
\hline
\end{tabular}

All estimates include only high school graduates. The likelihood of conviction is estimated using a logistic model of the probability of conviction as a function of all observables in the pre-2001 period. Heteroskedasticityrobust standard errors are in parentheses: $* *$ indicates significance at the $5 \%$ level and $*$ indicates significance at the $10 \%$ level. 


\section{Table 6: Effect of Conviction on College and High School Outcomes Surrounding Eligibility Policy Change}

\begin{tabular}{cccccc}
\hline \hline & $\begin{array}{c}\text { Ever Attend } \\
\text { College } \\
\text { Independent Variable }\end{array}$ & $\begin{array}{c}\text { BA } \\
\text { (ii) }\end{array}$ & $\begin{array}{c}\text { Time Between } \\
\text { HS \& Coll. } \\
\text { (iii) }\end{array}$ & $\begin{array}{c}\text { Time to } \\
\text { HS Degree } \\
\text { (iv) }\end{array}$ & $\begin{array}{c}\text { HS } \\
\text { Degree } \\
\text { (v) }\end{array}$ \\
\hline Post*Convicted & -0.080 & -0.072 & $27.98^{* *}$ & 3.82 & 0.075 \\
& $(0.105)$ & $(0.051)$ & $(8.01)$ & $(2.79)$ & $(0.068)$ \\
Convicted & $0.928^{*}$ & $0.909^{* *}$ & 52.50 & 16.26 & $-1.068^{* *}$ \\
& $(0.473)$ & $(0.317)$ & $(32.06)$ & $(15.53)$ & $(0.319)$ \\
Post-Change & 0.006 & -0.002 & $5.86^{*}$ & $6.98^{* *}$ & $-0.109 *$ \\
& $(0.083)$ & $(0.079)$ & $(3.40)$ & $(1.78)$ & $(0.060)$ \\
Pre-HEA98 & & & & & \\
Offender Mean & 0.410 & 0.074 & 8.44 & 242.85 & 0.631 \\
\hline \hline
\end{tabular}

${ }^{1}$ The "Pre-HEA98 Offender Mean" is the mean of the drug convict sample pre-2001. All estimates except the final column include only high school graduates. The Time to HS Degree is enumerated by the number of months since January 1, 1980. Time Between HS \& Coll. is the number of months between actual high school graduation and college enrollment.

${ }^{2}$ Heteroskedasticity-robust standard errors are in parentheses: ** indicates significance at the $5 \%$ level and * indicates significance at the $10 \%$ level. 
Table 7: Falsification Tests

\begin{tabular}{|c|c|c|c|c|c|c|c|c|}
\hline \multirow[b]{2}{*}{ Independent Variable } & \multicolumn{2}{|c|}{$\begin{array}{c}\text { Charged in Last } \\
\text { Two Years }\end{array}$} & \multicolumn{2}{|c|}{$\begin{array}{c}\text { Charged but } \\
\text { Not Convicted }\end{array}$} & \multicolumn{2}{|c|}{$\begin{array}{c}\text { Convicted Three or } \\
\text { More Years Ago }\end{array}$} & \multicolumn{2}{|c|}{$\begin{array}{l}\text { Including Non- } \\
\text { Drug Convictions }\end{array}$} \\
\hline & (i) & (ii) & (iii) & (iv) & $(\mathrm{v})$ & (vi) & (vii) & (viii) \\
\hline \multirow{2}{*}{ Post ${ }^{*}$ Convicted/Charged } & 0.015 & -0.056 & 0.172 & 0.058 & -0.025 & 0.137 & . & $-0.166^{*}$ \\
\hline & $(0.083)$ & $(0.076)$ & $(0.117)$ & $(0.102)$ & $(0.304)$ & $(0.103)$ & . & $(0.100)$ \\
\hline \multirow{2}{*}{ Convicted/Charged } & $-0.220^{* *}$ & 0.368 & $-0.176^{* *}$ & 0.276 & $-0.621^{* *}$ & $-0.376^{* *}$ & . & -0.091 \\
\hline & $(0.061)$ & $(0.325)$ & $(0.085)$ & $(0.432)$ & $(0.008)$ & $(0.083)$ & . & $(0.075)$ \\
\hline \multirow{2}{*}{ Post*Non-Drug Conviction } & $\cdot$ & $\cdot$ & - & . & $\cdot$ & . & -0.069 & -0.036 \\
\hline & . & . & . & . & . & . & $(0.057)$ & $(0.059)$ \\
\hline \multirow{2}{*}{ Non-Drug Conviction } & . & $\cdot$ & 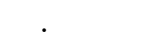 & . & . & . & 0.035 & 0.007 \\
\hline & . & . & . & . & . & . & $(0.224)$ & $(0.224)$ \\
\hline
\end{tabular}

${ }^{1}$ All estimates include only high school graduates. The estimates in columns (iii) and (iv) examine those who were charged with a drug offense in the past two years but who were not convicted. Estimates in columns (v) and (vi) examine those who have a drug conviction more than two years prior to the synthetic cohort graduation year. In the final two columns, we analyze non-drug offenses on the prior two years and drug and non-drug offenses simultaneously.

${ }^{2}$ Heteroskedasticity-robust standard errors are in parentheses: ${ }^{* *}$ indicates significance at the $5 \%$ level and ${ }^{*}$ indicates significance at the $10 \%$ level. 
Figure 1: Trends in College Enrollment Rates by Conviction Status and High School Cohort

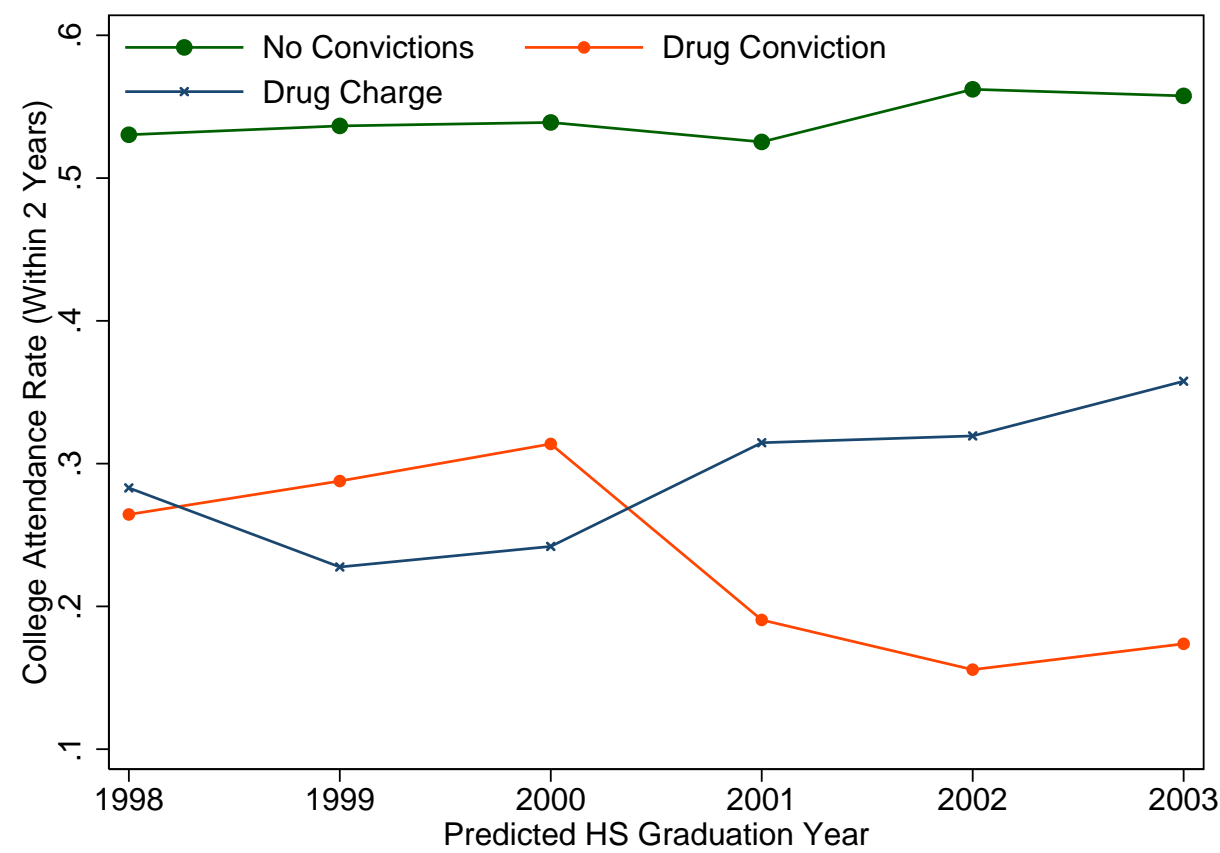

Source: Author's calculations from the 1997 National Longitudinal Survey of Youth as described in the text. 


\section{Figure 2: Trends in Predicted Attendance by Conviction Status}

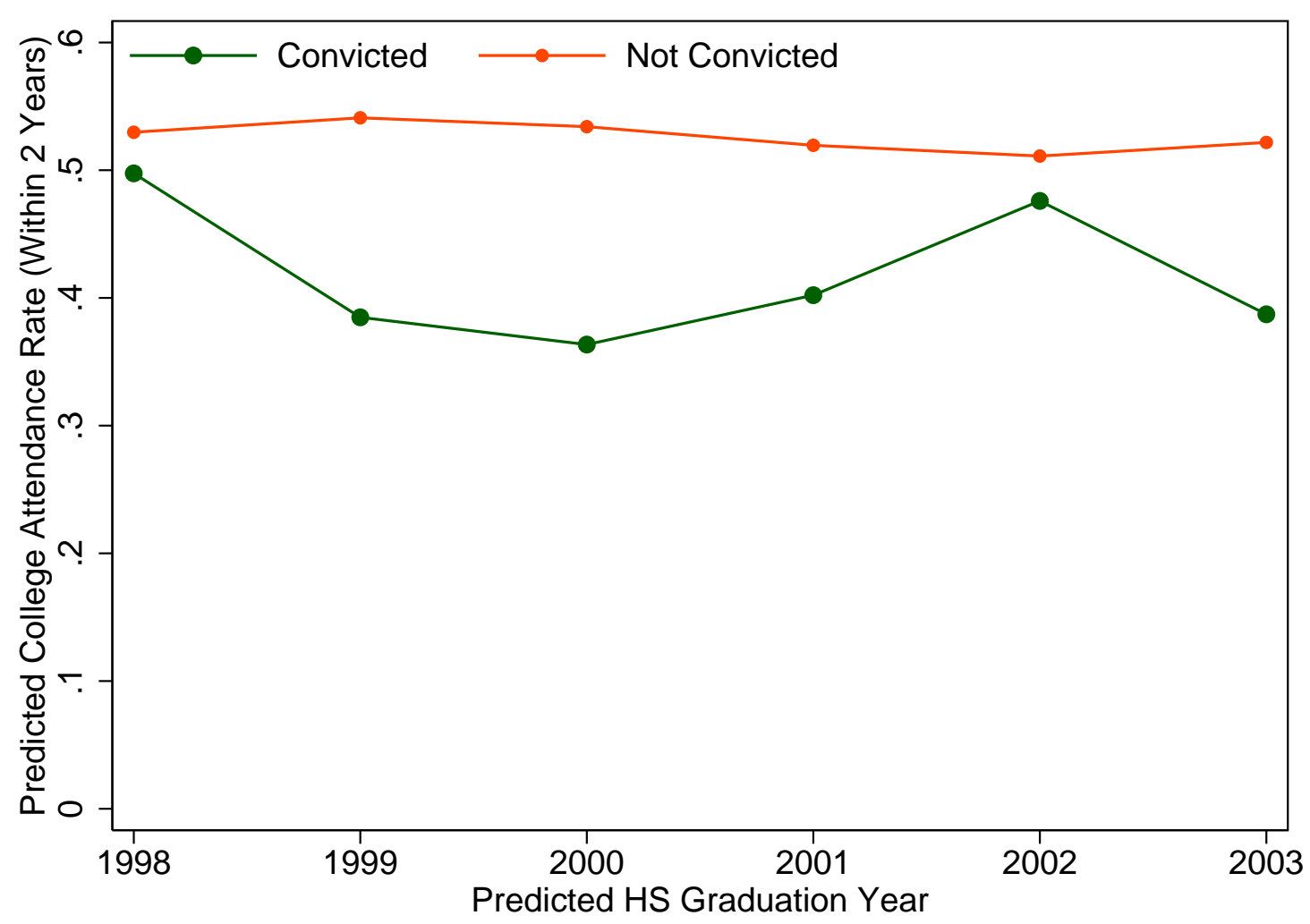

Source: Author's calculations from the 1997 National Longitudinal Survey of Youth as described in the text. The figure shows yearly average predicted attendance rates, where the predictions are made by estimating a logit model of the likelihood of enrolling within two years of high school graduation on all observables (excluding year and conviction dummies) using pre-treatment data. The logit coefficients are then used to predict attendance for each student in the estimation sample. 
Figure 3: Permutation Tests
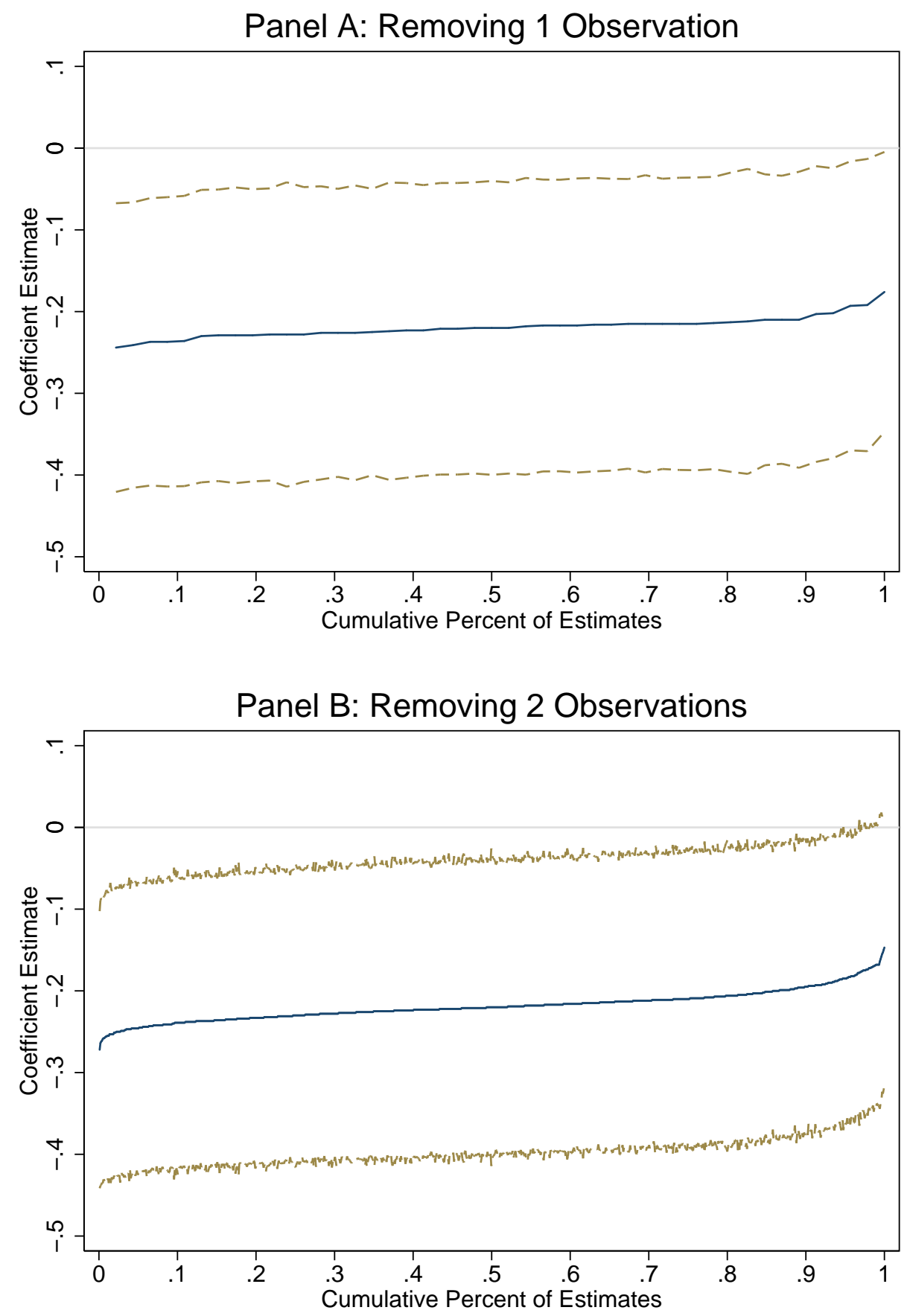

Source: Author's calculations from the 1997 National Longitudinal Survey of Youth as described in the text. In Panel A, we remove each of the 46 treated observations and re-estimate the model. The figure shows the inverse CDF of the resulting estimates with the bounds of the $95 \%$ confidence interval. In Panel $\mathrm{B}$, we remove each pair of two treated sample members and plot the inverse CDF of resulting estimates along with the bounds of the $95 \%$ confidence interval. 
Table A-1: Balance Tests and Sensitivity Analyses

\begin{tabular}{|c|c|c|}
\hline Variable & $\begin{array}{l}\text { Variable as } \\
\text { Outcome }\end{array}$ & $\begin{array}{l}\text { Variable(s) Excluded } \\
\text { from Model }\end{array}$ \\
\hline ASVAB (10,000 units) & $\begin{array}{l}7.683 \\
(6.394)\end{array}$ & $-0.214^{* *}$ \\
\hline Missing ASVAB & $\begin{array}{l}-0.008 \\
(0.085)\end{array}$ & $(0.091)$ \\
\hline Household Income $(\$ 10,000)$ & $\begin{array}{l}-0.424 \\
(0.516)\end{array}$ & $-0.218^{* *}$ \\
\hline Missing Income & $\begin{array}{c}0.084 \\
(0.086)\end{array}$ & $(0.088)$ \\
\hline Single Parent & $\begin{array}{l}-0.010 \\
(0.099)\end{array}$ & $-0.166^{*}$ \\
\hline Other Parental Structure & $\begin{array}{l}-0.072 \\
(0.052)\end{array}$ & $(0.093)$ \\
\hline \# HH Members $<18$ & $\begin{array}{l}-0.239 \\
(0.206)\end{array}$ & $\begin{array}{l}-0.216^{* *} \\
(0.091)\end{array}$ \\
\hline Urban & $\begin{array}{c}0.035 \\
(0.080)\end{array}$ & $\begin{array}{l}-0.232^{* *} \\
(0.091)\end{array}$ \\
\hline Mom Age at $1^{\text {st }}$ Birth & $\begin{array}{l}-0.878 \\
(0.610)\end{array}$ & $\begin{array}{l}-0.200^{* *} \\
(0.093)\end{array}$ \\
\hline Mom Age at Respondent Birth & $\begin{array}{l}0.686 \\
(0.639)\end{array}$ & $\begin{array}{l}-0.201^{* *} \\
(0.091)\end{array}$ \\
\hline Northeast & $\begin{array}{l}-0.042 \\
(0.095)\end{array}$ & \\
\hline South & $\begin{array}{l}-0.007 \\
(0.098)\end{array}$ & $\begin{array}{l}-0.223^{* *} \\
(0.096)\end{array}$ \\
\hline West & $\begin{array}{c}0.069 \\
(0.094)\end{array}$ & \\
\hline Mother < High School & $\begin{array}{r}0.106^{*} \\
(0.064)\end{array}$ & \\
\hline Mother Some College & $\begin{array}{l}-0.076 \\
(0.095)\end{array}$ & $-0.217^{* *}$ \\
\hline Mother BA+ & $\begin{array}{c}0.068 \\
(0.084)\end{array}$ & $(0.093)$ \\
\hline Mother Missing Education & $\begin{array}{c}0.008 \\
(0.035)\end{array}$ & \\
\hline Father $<$ High School & $\begin{array}{l}-0.085 \\
(0.078)\end{array}$ & \\
\hline Father Some College & $\begin{array}{c}0.011 \\
(0.084)\end{array}$ & $-0.184^{*}$ \\
\hline Father BA+ & $\begin{array}{c}0.031 \\
(0.063)\end{array}$ & $(0.095)$ \\
\hline Father Missing Education & $\begin{array}{c}0.029 \\
(0.096)\end{array}$ & \\
\hline Black & $\begin{array}{l}-0.025 \\
(0.070)\end{array}$ & $-0.229^{* *}$ \\
\hline Hispanic & $\begin{array}{l}-0.082 \\
(0.066)\end{array}$ & $(0.086)$ \\
\hline Male & $\begin{array}{c}0.034 \\
(0.085)\end{array}$ & $\begin{array}{l}-0.221^{* *} \\
(0.091)\end{array}$ \\
\hline Predicted College Attendance & $\begin{array}{c}0.061 \\
(0.057)\end{array}$ & $\begin{array}{l}-0.167^{*} \\
(0.102)\end{array}$ \\
\hline
\end{tabular}

All estimates include only high school graduates. In the first column, we show estimates of equation (1) with the given variable as the dependent variable and excluded from the right hand side. In the case of categorical or related variables (such as family income and missing family income), the relevant set of variables is excluded from the right hand side of the regression. In the second column, we show estimates of equation (1) with the given variable or set of variables excluded. The last row of the table uses predicted attendance based on a logit model of attendance on all observables as a dependent variable, while the second column shows estimates of equation (1) but using predicted attendance, predicated attendance times Post and predicted attendance times Convicted as controls instead of all of the observables and their interactions. Standard errors are in parentheses: ** indicates significance at the $5 \%$ level and $*$ indicates significance at the $10 \%$ level. 
Table A-2: Effect of Conviction on College and High School Outcomes Surrounding Eligibility Policy Change for Subsamples

\begin{tabular}{|c|c|c|c|c|c|}
\hline \multicolumn{6}{|c|}{ Panel A: Mother Did Not Attend College } \\
\hline Independent Variable & $\begin{array}{l}\text { Ever Attend } \\
\text { College } \\
\text { (i) }\end{array}$ & $\begin{array}{l}\text { BA } \\
\text { (ii) }\end{array}$ & $\begin{array}{l}\text { Time Between } \\
\text { HS \& Coll. } \\
\text { (iii) }\end{array}$ & $\begin{array}{l}\text { Time to } \\
\text { HS Degree } \\
\text { (iv) }\end{array}$ & $\begin{array}{c}\text { HS } \\
\text { Degree } \\
(\mathrm{v})\end{array}$ \\
\hline Post*Convicted & $\begin{array}{l}-0.226^{* *} \\
(0.116)\end{array}$ & $\begin{array}{l}-0.114^{* *} \\
(0.076)\end{array}$ & $\begin{array}{c}3.28 \\
(2.29)\end{array}$ & $\begin{array}{c}4.63 \\
(5.23)\end{array}$ & $\begin{array}{l}0.213^{* *} \\
(0.087)\end{array}$ \\
\hline $\begin{array}{l}\text { Pre-HEA98 } \\
\text { Offender Mean }\end{array}$ & 0.510 & 0.085 & 17.76 & 244.38 & 0.484 \\
\hline \multicolumn{6}{|c|}{ Panel B: Urban Sample } \\
\hline Independent Variable & $\begin{array}{l}\text { Ever Attend } \\
\text { College } \\
\text { (i) }\end{array}$ & $\begin{array}{l}\text { BA } \\
\text { (ii) }\end{array}$ & $\begin{array}{c}\text { Time Between } \\
\text { HS \& Coll. } \\
\text { (iii) }\end{array}$ & $\begin{array}{l}\text { Time to } \\
\text { HS Degree } \\
\text { (iv) }\end{array}$ & $\begin{array}{c}\text { HS } \\
\text { Degree } \\
(\mathrm{v})\end{array}$ \\
\hline Post*Convicted & $\begin{array}{l}-0.092 \\
(0.105)\end{array}$ & $\begin{array}{l}-0.044 \\
(0.038)\end{array}$ & $\begin{array}{l}31.11^{* *} \\
(7.98)\end{array}$ & $\begin{array}{c}0.73 \\
(3.01)\end{array}$ & $\begin{array}{c}0.076 \\
(0.071)\end{array}$ \\
\hline $\begin{array}{c}\text { Pre-HEA98 } \\
\text { Offender Mean }\end{array}$ & 0.425 & 0.045 & 16.04 & 243.49 & 0.674 \\
\hline \multicolumn{6}{|c|}{ Panel C: Above Median Predicted Likelihood of Conviction } \\
\hline Independent Variable & $\begin{array}{l}\text { Ever Attend } \\
\text { College } \\
\text { (i) }\end{array}$ & $\begin{array}{l}\text { BA } \\
\text { (ii) }\end{array}$ & $\begin{array}{l}\text { Time Between } \\
\text { HS \& Coll. } \\
\text { (iii) }\end{array}$ & $\begin{array}{l}\text { Time to } \\
\text { HS Degree } \\
\text { (iv) }\end{array}$ & $\begin{array}{c}\text { HS } \\
\text { Degree } \\
(\mathrm{v})\end{array}$ \\
\hline Post*Convicted & $\begin{array}{l}-0.035 \\
(0.487)\end{array}$ & $\begin{array}{l}-0.048 \\
(0.051)\end{array}$ & $\begin{array}{l}15.67^{* *} \\
(2.90)\end{array}$ & $\begin{array}{c}4.67 \\
(3.24)\end{array}$ & $\begin{array}{c}0.038 \\
(0.068)\end{array}$ \\
\hline $\begin{array}{l}\text { Pre-HEA98 } \\
\text { Offender Mean }\end{array}$ & 0.339 & 0.051 & 12.93 & 241.64 & 0.572 \\
\hline
\end{tabular}

${ }^{1}$ The "Pre-HEA98 Offender Mean" is the mean of the drug convict sample pre-2001. All estimates except the final column include only high school graduates. The Time to HS Degree is enumerated by the number of months since January 1, 1980. Time Between HS \& Coll. is the number of months between actual high school graduation and college enrollment. The likelihood of conviction is estimated using a logistic model of the probability of conviction as a function of all observables in the pre-2001 period.

${ }^{2}$ Heteroskedasticity-robust standard errors are in parentheses: ** indicates significance at the $5 \%$ level and * indicates significance at the $10 \%$ level. 